\title{
Perancangan Konveyor Pengangkat Sampah dari Dasar Sungai
}

\author{
Jamal M. Afiff ${ }^{1, a)}$, Tono Sukarnoto ${ }^{1, b)}$, dan Michael Siebert ${ }^{1, \mathrm{c}}$ \\ ${ }^{1)}$ Program Studi Teknik Mesin, Fakultas Teknologi Industri, Universitas Trisakti. \\ Jl. Kyai Tapa No.1, RT. 4 / RW. 16, Tomang, Kec. Grogol Petamburan, Jakarta, Indonesia, 11440. \\ a)jamal@trisakti.ac.id (corresponding author), b)tsukarnoto@trisakti.ac.id, ${ }^{c}$ twinssiebert@gmail.com
}

\begin{abstract}
Abstrak
Di Indonesia, sampah terdapat dimana-mana khususnya di daerah perkotaan dan sekarang menjadi masalah terbesar yang dihadapi manusia saat ini. Banyak solusi yang ditawarkan pemerintah setempat, seperti penggunaan wiremash dan excavator dengan pasukan oranye yang banyak melibatkan tenaga kerja. Untuk mengurangi keterlibatan banyak tenaga kerja, perlu dirancang konveyor pengangkat sampah secara otomatis dari dasar sungai. Perancangan diawali dengan pengumpulan data, pembuatan konsep rancangan, pemilihan konsep rancangan, perhitungan serta analisis untuk mengetahui defleksi pada poros dan pembuatan gambar teknik dengan software Solidworks.. Hasil rancangan ini menggunakan konveyor sabuk Mitsuboshi dengan kecepatan $0,8 \mathrm{~m} / \mathrm{s}$, bucket, transmisi v-belt Mitsuboshi, motor AC TECO dan bantalan dari SKF. Konveyor pengangkat sampah ini akan ditempatkan di Sungai Sekretaris, Duri Kepa, Jakarta Barat. Rancangan pun memakai sistem belt bucket conveyor yang bekerja secara kontinyu.
\end{abstract}

Kata Kunci: sampah, belt conveyor, sungai, solidworks.

\begin{abstract}
In Indonesia, waste is everywhere, especially in urban areas and now become the biggest problem that humans are facing today. At this time, many solutions offered by the local government, such as wiremash and excavators with pasukan oranye as operator that involve a lot of manpower. To reduce the manpower, it is necessary to design a conveyor to lift the trash automatically from the bottom of the river. The design begins with collecting the main data, making the design concepts, selecting the suitable the design concepts, calculations and analysis to get the deflection in shaft, and technical drawing in Solidworks software. The result of this design uses a belt conveyor Mitsuboshi with a speed of $0.8 \mathrm{~m} / \mathrm{s}$, bucket, Mitsuboshi v-belt transmission, TECO AC motor and bearings from SKF which will be placed in Sungai Sekretaris, Duri Kepa, West Jakarta. The design uses a belt bucket conveyor system that working continuously.
\end{abstract}

Keywords: waste, belt conveyor, river, solidworks.

\section{PENDAHULUAN}

Sampah merupakan benda sisa yang tidak bernilai atau tidak berharga lagi yang ada di sekitar lingkungan tempat tinggal suatu masyarakat. Di Indonesia, sampah terdapat dimana-mana khususnya di daerah perkotaan dan menjadi masalah terbesar yang dihadapi manusia saat ini. Sebahagian dari sampah akan terbuang ke sungai dan akan mencemari sungai tersebut. Pada akhirnya sampah akan terbawa oleh aliran arus sungai menuju ke laut lepas. Hal ini merupakan bencana bagi mahluk hidup tidak hanya di sungai, namun juga kehidupan yang ada di laut. Sering didapati ikan-ikan mati karena keberadaan sampah plastik dan juga kehidupan terumbu karang pun menjadi tercemar.

Pada saat ini, sudah ada solusi yang ditawarkan pemerintah setempat, seperti penggunaan wiremash, excavator dengan pasukan oranye-nya. Namun solusi ini masih mempunyai banyak kekurangan, salah satunya adalah diperlukan banyak sumber daya manusia (SDM) yang ikut serta sehingga kemampuan dan jam kerja dari solusi penanganan sampah ini menjadi terbatas. Keterbatasan ini akan mengakibatkan penumpukan sampah dan aliran sungai akan tersumbat. Maka perlu adanya metode baru yang dapat mengatasi permasalahan tersebut, salah satunya dengan pengangkatan secara bertahap tanpa perlu melibatkan banyak operator atau dengan kata lain hanya dengan melibatkan operator seminimum mungkin.

Melihat permasalahan di atas, maka perlu dirancang suatu peralatan untuk mengangkat sampah secara otomatis dari dasar sungai. Pada rancangan ini dipilih peralatan tipe belt conveyor yang dimodifikasi sehingga pemakaiannya efektif dan efisien [1].

Perancangan belt conveyor pengangkat sampah dari dasar sungai ini dibatasi pada hal-hal sebagai berikut:
a. Tipe Conveyor
: Bucket belt conveyor.
b. Mekanisme kerja
: Kontinyu.
c. Kapasitas maksimal
: 288 ton/hr.
d. Lebar sungai
: $2 \sim 3 \mathrm{~m}$.
e. Kedalaman sungai
: $50 \sim 200 \mathrm{~cm}$.
f. Jenis sampah
g. Volume sampah
: Organik dan Anorganik.
h. Beban angkut bucket $: \leq 100 \mathrm{~N}$
i. Jumlah bucket $: 14$.

\section{TINJAUAN PUSTAKA}

\section{A. Sampah}

Pengertian sampah menurut WHO (World Health Organization) adalah sebuah materi yang tidak terpakai, 
tidak disenangi, tidak digunakan, atau segala sesuatu yang berasal dari kegiatan manusia dan telah dibuang [2]. Sampah merupakan sisa kegiatan sehari-hari manusia dan/atau proses alam yang berbentuk padat, pengertian menurut undang-undang Republik Indonesia Nomor 18 Tahun 2008 [3]. Sampah yang dikelola berdasarkan sesuai yang tertulis pada undang-undang Republik Indonesia Nomor 18 Tahun 2008 pasal 2, sampah terdiri atas:

\section{a. Sampah rumah tangga.}

b. Sampah rumah tangga merupakan jenis sampah yang berasal dari rumah tangga, tidak termasuk tinja dan sampah spesifik.

c. Sampah sejenis sampah rumah tangga.

d. Merupakan jenis sampah yang berasal dari kawasan komersial, kawasan industri, kawasan khusus, fasilitas sosial, fasilitas umum, dan/atau fasilitas lainnya.

e. Sampah spesifik, merupakan jenis sampah yang meliputi:

1. Sampah yang mengandung bahan berbahaya dan beracun.

2. Sampah yang mengandung limbah bahan berbahaya dan beracun.

3. Sampah yang timbul akibat bencan.

4. Puing bongkaran bangunan.

5. Sampah yang secara teknologi belum dapat diolah dan/atau

6. Sampah yang timbul secara periodik.

\section{B. Sumber Sampah}

Mengacu pada data dari Sistem Informasi Pengelolaan Sampah Nasional (SIPSN) - Kementrian Lingkungan Hidup dan Kehutanan pada tahun 2020, terdapat 6 sumber yang merupakan penyumbang terbanyak sampah yang ada saat ini seperti ditunjukkan pada Gambar 1, yaitu [4] :

a. Sampah yang berasal dari rumah tangga

Menurut grafik, sampah yang berasal dari rumah tangga merupakan penyumbang terbesar dengan presentase $37,4 \%$. Menurut data dari sumber yang sama, hampir setiap rumah menghasilkan sampah paling sedikit $0,3 \mathrm{~kg}$ tiap harinya. Kebanyakan sampah ini berupa sisa-sisa makanan, pembungkus makanan, botol plastik, pakaian, dan lain sebagainya.

b. Sampah yang berasal dari perkantoran

Sampah yang berasal dari perkantoran menyumbang sampah dengan presentase paling kecil yaitu, 3,2\%. Perkantoran disini meliputi semua perkantoran yang ada baik itu perkantoran sederhana maupun perkantoran besar. Kebanyakan sampah ini berupa kertas-kertas dan dokumen ataupun alat-alat perkantoran yang sudah tidak terpakai lagi.

c. Sampah yang berasal dari pasar tradisional

Sampah yang berasal dari pasar tradisional merupakan penyumbang sampah terbesar kedua dengan presentase 16,4\%. Dimana sampah ini biasanya berupa bahan makanan sisa atau yang tidak layak dikonsumsi lagi, kantong plastik, dan makanan.

d. Sampah yang berasal dari pusat perniagaan

Sampah yang berasal dari pusat perniagaan menyumbang sampah sebesar 7,3\%. e. Sampah yang berasal dari fasilitas publik

Sampah ini menyumbang sekitar 5,3\%. Biasanya sampah ini kebanyakan terdiri dari kantong plastik, botol plastik, sterofoam, dan bungkus rokok maupun rokok itu sendiri.

f. Sampah yang berasal dari kawasan lainnya

Sampah dari kawasan lainnya ini merupakan penyumbang terbesar ketiga setelah pasar tradisional dengan presentase $16 \%$ [5].

\section{Komposisi Sampah Berdasarkan Sumber Sampah}
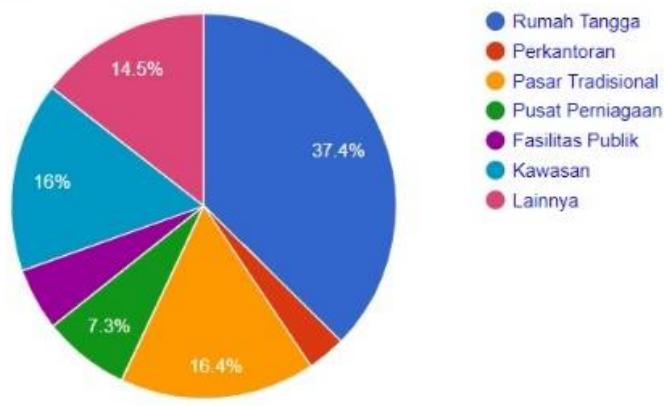

Gambar 1. Diagram komposisi sampah berdasarkan sumber sampah [4]

\section{Belt Conveyor}

Konveyor adalah salah satu material handling yang berfungsi untuk memindahkan barang dari suatu tempat ke tempat lainnya, yang dimana jalur perpindahan tidak berpindah-pindah atau tetap. Konveyor pada umumnya memiliki dua atau lebih puli, yang disambungkan melalui sabuk. Puli yang pertama disebut puli penggerak, yang fungsinya untuk menggerakan puli lainnya. Sebuah sistem tertutup dibentuk oleh sabuk sehingga puli dapat terus-menerus berputar. Sistem konveyor mempunyai beberapa manfaat, yang utamanya adalah untuk memindahkan barang dalam jumlah banyak. Beberapa manfaat yang lain yaitu, mengurangi resiko kecelakaan kerja, meningkatkan efisiensi waktu dan tenaga, mengurangi biaya buruh atau pekerja, dan sebagainya. Prinsip kerja belt conveyor adalah mentransfer material yang ada di atas belt, dimana umpan atau inlet pada sisi tail dengan menggunakan chute dan sesudah material di head, material dituangkan karena belt berbalik arah, drive/head pulley menggerakkan belt menggunakan motor penggerak. Belt ditarik head pulley menggunakan suatu prinsip yaitu gesekan antara permukaan drum dengan belt, sehingga gaya gesek tersebut memengaruhi kapasitasnya [6].

\section{Jenis-jenis Konveyor}

Konveyor sabuk atau dikenal sebagai belt conveyer menurut jenisnya terbagi menjadi 3, yaitu:

\section{a. Roller Bed Belt Conveyor}

Tipe Roller Bed Belt Conveyor ini mempunyai belt yang ditopang dengan roller yang mempunyai peran untuk menahan beban yang ada di atasnya. Dikarenakan memiliki gesekan yang minimum, roller ini dipilih. Konveyor ini memiliki batas-batas pada perancangan, terutamanya pada kemiringan. Roller 
bed belt conveyor ini tidak mempunyai kemampuan untuk kemiringan yang curam.

b. Slider Bed Belt Conveyor

Tipe slider bed belt conveyor ini mempunyai keunikan dimana bagian bawah belt ditopang menggunakan permukaan licin. Dasar dari konveyor ini merupakan pelat yang licin, terbuat dari UHMW (Ultra High Molecular Weight Polyethylene). Slider bed belt conveyor ini pun mempunyai batas-batas pada perancangannya jika dibandingkan dengan konveyor bertipe roller bed belt conveyor yaitu gaya gesek yang muncul lebih besar.

c. Bucket Elevator Belt Conveyor

Tipe bucket elevator belt conveyor ini mempunyai fungsi untuk mentransfer benda-benda curah seperti batu bara, biji-bijian, semen, tepung, pasir, kerikil, pupuk, dan banyak lainnya. Konveyor ini dapat bekerja secara horizontal maupun vertikal dengan bucket yang terpasang pada konveyor ini. Konveyor ini memiliki kekurangan dimana perancangannya lebih sulit dibanding konveyor lainnya. Konveyor ini pun memiliki kelebihan, dimana jika yang diperlukan itu ruangan kecil namun memiliki perbedaan ketinggian. Ini merupakan solusi paling tepat untuk masalah di atas. [6]

\section{E. Motor Induksi}

Motor induksi adalah salah satu motor AC yang banyak digunakan atau dilihat pada saat ini karena konstruksinya yang cukup kuat dan karakteristik kerjanya yang baik, serta motor ini dapat terbilang sangat sederhana. Motor induksi mempunyai beberapa bagian yaitu,

a. stator atau bagian yang diam

b. rotor atau bagian yang berputar

Diklasifikasikan menjadi dua tipe motor induksi tiga fasa yaitu motor rotor sangkar tupai dan motor rotor lilitan. Kedua motor tersebut menggunakan prinsip dasar yang sama dan mempunyai konstruksi stator yang serupa namun berbeda dalam konstruksi rotor. Dapat disebut motor induksi, karena dalam hal penerimaan tegangan dan arus pada rotor dilakukan dengan jalan induksi. Jadi pada rotor induksi, rotor tidak langsung menerima tegangan atau arus dari luar.

Secara umum motor induksti tiga fasa terdiri dari beberapa bagian yaitu [7] :
a. body (frame)
b. stator (bagian yang diam)
c. rotor (bagian yang bergerak)
d. belitan stator
e. bearing
f. name plate

\section{METODE PENELITIAN/EKSPERIMEN}

Perancangan ini akan memfokuskan untuk merancang konveyor pengangkut sampah dari dasar sungai sehingga nanti perancangan dapat bermanfaat bagi sekitar. Diagram alir proses perancangan ditunjukkan pada Gambar 2. Tahapan pada perancangan ini meliputi:

a. Pengumpulan Data
Pada bagian ini, dipersiapkan data untuk merancang konveyor sabuk pengangkat sampah, baik itu data yang dirancang atau yang terdapat pada literatur maupun sesuai kebutuhan yang didapati di lapangan. Terutama pada data utama yaitu: jenis sampah, ukuran sampah, dan dimensi sungai. Hal ini meupakan proses yang sangat vital karena dimensi dan penggunaan konveyor akan mengacu pada datadata yang ada pada bagian ini.

b. Studi Pustaka

Dalam studi pustaka, dicari dan dipelajari referensireferensi yang berhubungan dengan perancangan konveyor. Studi pustaka ini untuk memberi gambaran bagaimana alur dan proses perancangan dibuat.

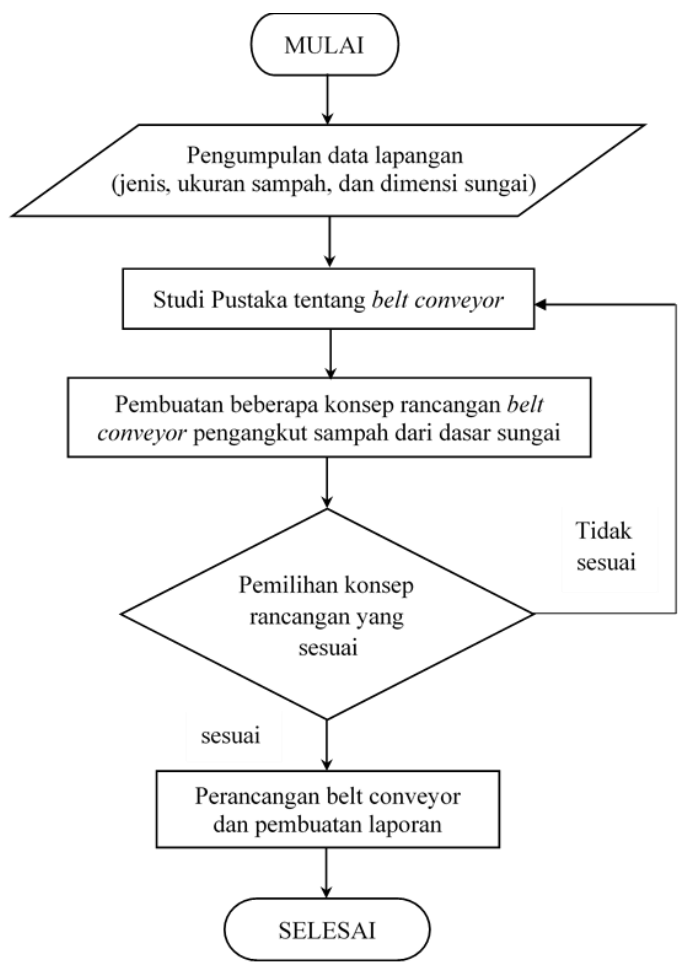

Gambar 2. Diagram alir proses penelitian

c. Pembuatan Konsep Rancangan

Pada proses ini, akan dibuat beberapa konsep rancangan. Dari beberapa konsep rancangan yang dibuat, akan ditentukan konsep rancangan terbaik, efektif, dan efisien. Hal ini akan mengurangi beberapa masalah yang dijumpai pada perancangan nanti.

d. Pemilihan konsep rancangan

Pada tahap ini, penulis akan memilih konsep rancangan berdasarkan prinsip solusi dan evaluasi konsep rancangan.

e. Perancangan Belt Conveyor dan Laporan

Pada tahap ini, akan dirancang desain konveyor sabuk menggunakan software Solidworks sesuai perhitungan yang telah dilakukan. Perhitungan dilakukan pada volume bucket, kapasitas bucket, dan gaya efektif pada bucket. Setelah didapatkan gaya efektif yang bekerja, akan dirancang dan dipilih tipe sabuk konveyor dan puli konveyor yang akan dipakai. Pemilihan motor dan spesifikasi motor yang 
digunakan. Perancang untuk tansmisi pada konveyor. Analisis dan perhitungan poros penggerak berikut pasak dan bantalan yang akan digunakan.

\section{HASIL DAN PEMBAHASAN}

Perancangan ini dilakukan dengan melihat beberapa masalah yang ada di lapangan. Survey telah dilakukan untuk menempatkan hasil perancangan ini. Spesifikasi pada rancangan mengacu pada tempat dan lokasi survey yang telah dilakukan di Sungai Sekretaris, Duri Kepa, Jakarta Barat.

\section{A. Spesifikasi Awal Rancangan Konveyor}

Pada awal tahapan rancangan ini, diperlukan beberapa spesifikasi awal rancangan yang telah disesuaikan dengan kebutuhan rancangan di lapangan, yaitu:
a. Lebar sungai
: 1,5 meter.
b. Kedalaman sungai
: 1 meter.
c. Dimensi sampah
: $0,125 \mathrm{~m}^{2}$.
d. Jarak antar kedua puli, C
: 2,83 meter.
e. Tinggi konveyor
: 2 meter.
f. Beban max. angkut bucket, $w b: 10 \mathrm{~kg}$.
g. Kecepatan konveyor, $v \quad: 0,8 \mathrm{~m} / \mathrm{s}$
h. Sudut Konveyor $: 45^{\circ}$.
i. Jarak antar bucket, $l \quad: 100 \mathrm{~mm}$.
j. Jari-jari bucket, $r \quad: 300 \mathrm{~mm}$.
k. Lebar bucket, $\mathrm{lb} \quad: 500 \mathrm{~mm}$.
1. Jumlah bucket $: 14$.
m. Jumlah bucket terisi : 7 .
n. Massa total bucket terisi, Mbt : $686 \mathrm{~N}$.
o. Kondisi konveyor
: Di air dan di darat.

\section{B. Struktur Fungsi}

Cara kerja dari sebuah konveyor sabuk dinyatakan dalam bentuk diagram blok pada gambar. Hubungan (fungsi transfer) antara masukan dan keluaran dinyatakan dalam setiap blok, sedangkan fungsi transfer itu sendiri berupa diteruskan, diubah, dibesarkan dan diproses. Pada Gambar 3 terdapat struktur fungsi global dan struktur aliran sampah di sungai.

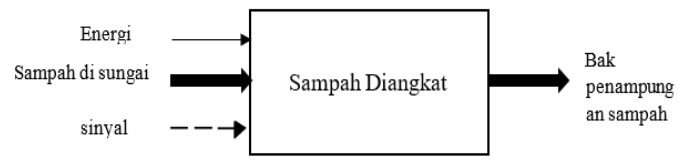

(a) Struktur Fungsi Global

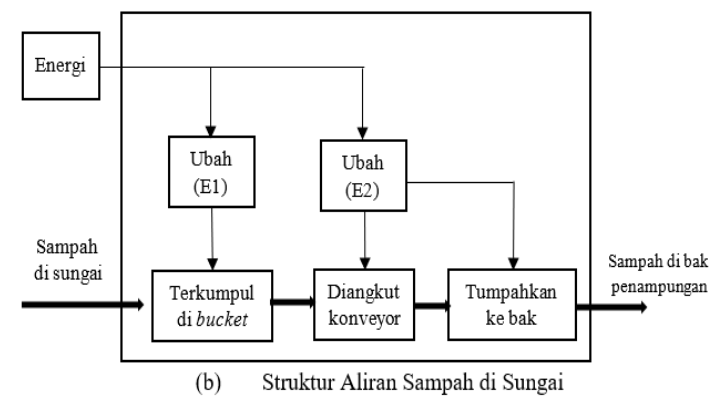

\section{Membuat Prinsip Solusi}

Prinsip solusi yang ditunjukkan pada Gambar 4 tersusun berupa matriks dari beberapa solusi yaitu solusi penggerak, solusi transmisi, solusi pengangkut. Pada akhir prinsip solusi akan diberikan pilihan perancangan yang paling mudah, efektif, dan efisien berdasarkan data lapangan [8].

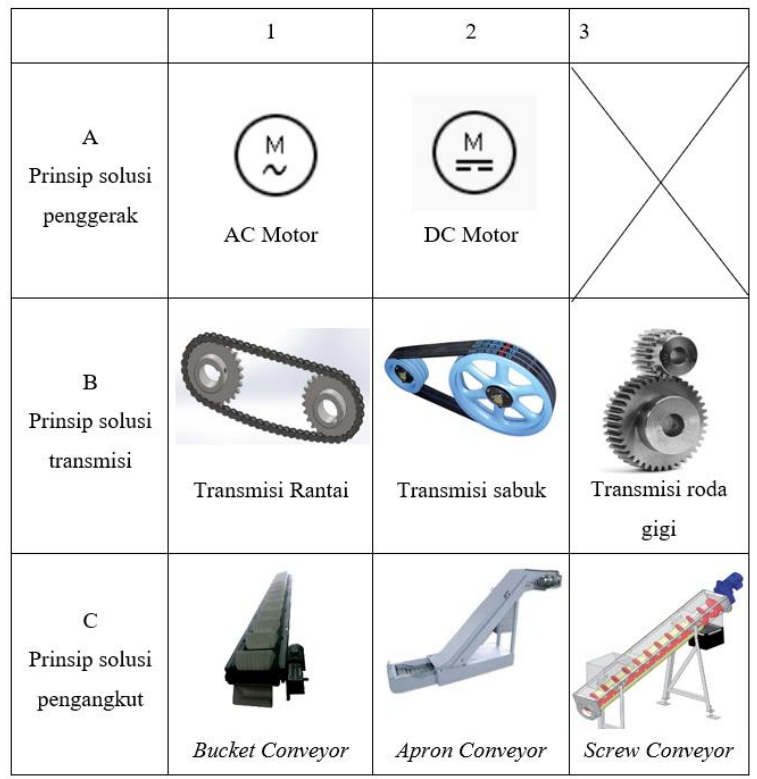

Gambar 4. Prinsip solusi

Dari beberapa prinsip solusi pada Tabel 1, terdapat beberapa variasi konsep rancangan yang bisa dibuat, yaitu:
1. Varian 1: A1-B1-C1 6. Varian 6: A1-B1-C2
2. Varian 2: A2-B2-C2 7. Varian 7: A2-B1-C2
3. Varian 3: A1-B2-C1 8. Varian 8: A2-B2-C1
4. Varian 4: A1-B3-C1 9. Varian 9: A1-B2-C3
5. Varian 5: A2-B3-C1 10. Varian 10: A1-B3-C3

\section{Pemilihan Konsep Rancangan}

Pemilihan konsep rancangan terbaik dari 10 variasi konsep rancangan berdasarkan indikasi dan alasan yang telah dibuat seperti ditunjukkan pada Gambar 5 [8].

Gambar 3. Strukur fungsi rancangan 


\begin{tabular}{|c|c|c|c|c|c|c|c|c|c|}
\hline \multicolumn{8}{|c|}{$\begin{array}{l}\text { Varian solusi dengan kriteria solusi } \\
\text { (+) Ya } \\
\text { (-) Tidak } \\
\text { (?) Kekurangan informasi } \\
\text { (!) Periksa spesifikasi }\end{array}$} & \multicolumn{2}{|l|}{$\begin{array}{l}\text { Keputusan tanda solusi varian } \\
\text { (+) Mengikat solusi } \\
\text { (-) Menghilangkan solusi } \\
\text { (?) Mengumpulkan informasi } \\
\text { (!) Memeriksa spesifikasi }\end{array}$} \\
\hline & \multicolumn{8}{|c|}{ Sesuai dengan fungsi keseluruhan } & \\
\hline & & \multicolumn{7}{|c|}{ Secara prinsip dapat diwujudkan } & \\
\hline & & \multicolumn{7}{|c|}{ Pengetahuan tentang konsep memadai } & \\
\hline & & & & \multicolumn{5}{|c|}{ Sesuai dengan keinginan pembuat } & \\
\hline & & & & & \multicolumn{4}{|c|}{ Memenuhi syarat keamanan } & \\
\hline & & & & & & \multicolumn{3}{|c|}{ Mudah dioperasikan } & \\
\hline Variasi & $\mathrm{A}$ & $\mathrm{B}$ & $\mathrm{C}$ & $\mathrm{D}$ & $E$ & $\mathrm{~F}$ & & Keterangan & Hasil \\
\hline V1 & + & + & + & - & + & & \multicolumn{2}{|c|}{$\begin{array}{l}\text { Memerlukan biaya perawatan lebih dan } \\
\text { diperlukan pelumasan }\end{array}$} & - \\
\hline $\mathrm{V} 2$ & - & + & - & - & + & - & \multicolumn{2}{|c|}{$\begin{array}{l}\text { Apron conveyor tidak dapat } \\
\text { mengangkut sampah dari dasar sungai }\end{array}$} & - \\
\hline V3 & + & + & + & + & + & + & \multicolumn{2}{|c|}{ Sesuai } & + \\
\hline $\mathrm{V} 4$ & + & + & + & - & + & + & \multicolumn{2}{|c|}{ Jarak antar poros jauh } & - \\
\hline V5 & + & + & + & - & + & - & \multicolumn{2}{|c|}{ Harganya lebih mahal } & - \\
\hline V6 & + & + & + & - & + & + & \multicolumn{2}{|c|}{ Bisa melebihi dimensi rancangan } & - \\
\hline V7 & - & - & + & - & & & \multicolumn{2}{|c|}{$\begin{array}{l}\text { Apron conveyor tidak dapat } \\
\text { mengangkut sampah dari dasar sungai }\end{array}$} & - \\
\hline V8 & + & + & + & - & + & + & \multicolumn{2}{|c|}{ Harganya lebih mahal } & - \\
\hline V9 & - & & - & & & & \multicolumn{2}{|c|}{$\begin{array}{l}\text { Screw conveyor tidak dapat } \\
\text { mengangkut sampah dari dasar sungai }\end{array}$} & - \\
\hline V10 & $!$ & $!$ & - & - & & & \multicolumn{2}{|c|}{ Kombinasi sulit direalisasikan } & - \\
\hline
\end{tabular}

Gambar 5. Pemilihan kombinasi

Sesuai Gambar 5, pemilihan kombinasi terdapat satu varian yang mengikat solusi semua kriteria yang dievaluasi, yaitu varian 3 (V3). Gambar 6 menunjukan sebuah sketsa dari rancangan berdasarkan varian 3 tersebut.

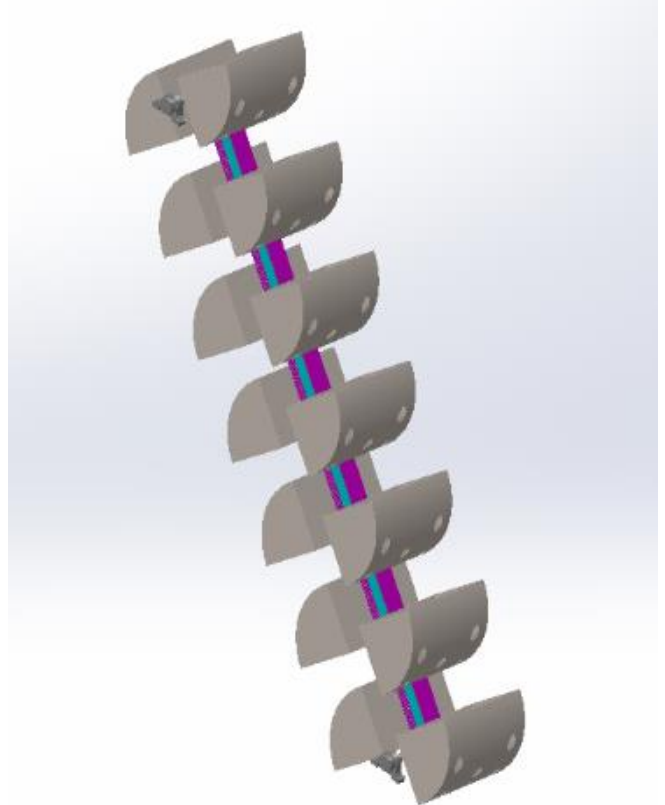

Gambar 6. Konsep rancangan terpilih

\section{E. Perhitungan Kapasitas Konveyor}

Besar volume bucket dapat dihitung sebagai berikut:

$$
\begin{aligned}
V & =\frac{1}{4} \pi r^{2} \cdot l b \\
& =\frac{1}{4} \pi \cdot(300)^{2} \cdot(500)=35 \cdot 342 \cdot 917,4 \mathrm{~mm}^{3} \\
& =0,035 \mathrm{~m}^{3} .
\end{aligned}
$$

Besar kapasitas bucket, $Q$ adalah:

$$
\begin{aligned}
Q & =\frac{3600 \cdot W b}{(l / v)} \\
& =\frac{3600 \cdot(10)}{(0,1 / 0,8)}=288.000 \mathrm{~kg} / \mathrm{hr}=288 \mathrm{ton} / \mathrm{hr}
\end{aligned}
$$

Perancangan Belt dan Puli Konveyor

Gaya yang bekerja pada konveyor,

$$
\begin{aligned}
\mathrm{Wy} & =\mathrm{F} \cdot \cos 45^{\circ} \\
& =\mathrm{Mbt} \cdot \cos 45^{\circ} \\
& =686 \cdot\left(\cos 45^{\circ}\right)=485,08 \mathrm{~N} . \\
\mathrm{Wx} & =\mathrm{F} \cdot \sin 45 \cdot \mu \\
& =\mathrm{Mbt} \cdot \sin 45^{\circ} \cdot \mu \\
& =686 \cdot\left(\sin 45^{\circ}\right) \cdot(0,7)=339,55 \mathrm{~N} . \\
\mathrm{Fk} \quad \mathrm{Wy}+\mathrm{Wx} & \\
& =485,08 \mathrm{~N}+339,55 \mathrm{~N} \\
& =824,63 \mathrm{~N} . \\
\mathrm{P} & =\mathrm{Fk} \cdot \mathrm{v} \\
& =824,63 \cdot(0,8) \\
& =659,70 \mathrm{~W} . \\
& =0,66 \mathrm{~kW}=0,89 \mathrm{Hp} .
\end{aligned}
$$

Pehitungan putaran maksimum, (Nmax) [9]

$$
\begin{aligned}
& N_{\max }=\frac{v \times 19 \cdot 100}{D p_{\min }} \\
& =\frac{0,8 \cdot(19 \cdot 100)}{18,27}=836,34 \mathrm{rpm} \approx 837 \mathrm{rpm} .
\end{aligned}
$$

Dari $N_{\max }$ yang telah dihitung, dipilih profil gigi belt yang sesuai berdasarkan Gambar 7. Mengacu pada $N_{\max }=837 \mathrm{rpm}$ dan $\mathrm{P}=0,66 \mathrm{~kW}$, dipilih profil gigi belt $\mathrm{T} 10$.

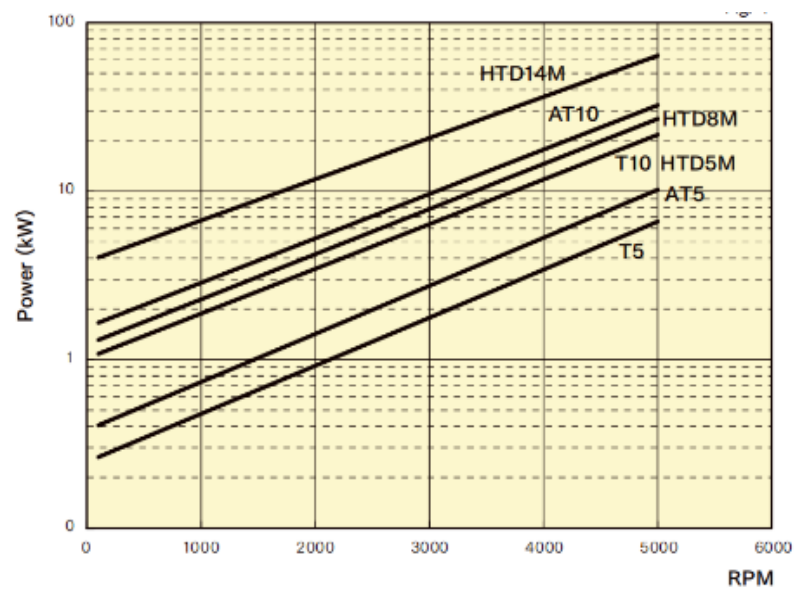

Gambar 7. Grafik pemilihan profil gigi

\section{F. Pemilihan Puli [10]}

Gambar 8 menunjukan tabel pemilihan puli. Berdasarkan kebutuhan rancangan akan dipilih puli dengan spesifikasi berikut:
a. No. of teeth, Z: 30
b. Pulley type
: A. B
c. Material
: Steel
d. Outer Diameter. OD
: $93,65 \mathrm{~mm}$ 
e. Pitch Diameter, Dp : : 95,49 mm

\begin{tabular}{|c|c|c|c|c|c|c|}
\hline Tooth Profile & & & & T10 & & \\
\hline $\begin{array}{l}\text { No. of } \\
\text { teeth }\end{array}$ & $\begin{array}{l}\text { Pulley } \\
\text { Type }\end{array}$ & Material & $\begin{array}{c}\mathrm{OD} \\
(\mathrm{mm})\end{array}$ & $\begin{array}{l}\text { PD } \\
\text { (mm) }\end{array}$ & Produ & $t$ Code \\
\hline 12 & $A \cdot B$ & & 36.35 & 38.20 & PT10-15-12 & PT10-25-12 \\
\hline 14 & $A \cdot B$ & & 42.70 & 44.56 & PT 10-15-14 & PT10-25-14 \\
\hline 15 & $A \cdot B$ & & 45.90 & 47.75 & PT 10-15-15 & PT10-25-15 \\
\hline 16 & $A \cdot B$ & & 49.05 & 50.93 & PT 10-15-16 & PT10-25-16 \\
\hline 18 & $A \cdot B$ & & 55.45 & 57.30 & PT10-15-18 & PT10-25-18 \\
\hline 20 & $A \cdot B$ & & 61.80 & 63.66 & PT $10-15-20$ & PT10-25-20 \\
\hline 22 & $A \cdot B$ & & 68.15 & 70.03 & PT 10-15-22 & PT10-25-22 \\
\hline 24 & $A \cdot B$ & Steel & 74.55 & 76.39 & PT 10-15-24 & PT10-25-24 \\
\hline 25 & $A \cdot B$ & & 77.70 & 79.58 & PT 10-15-25 & PT10-25-25 \\
\hline 26 & $A \cdot B$ & & 80.90 & 82.76 & PT 10-15-26 & PT10-25-26 \\
\hline 28 & $A \cdot B$ & & 87.25 & 89.13 & PT 10-15-28 & PT10-25-28 \\
\hline 30 & $A \cdot B$ & & 93.65 & 95.49 & PT 10-15-30 & PT $10-25-30$ \\
\hline 32 & $A \cdot B$ & & 100.00 & 101.86 & PT 10-15-32 & PT10-25-32 \\
\hline 36 & $A \cdot B$ & & 112.75 & 114.59 & PT $10-15-36$ & PT10-25-36 \\
\hline 40 & $A \cdot B$ & & 125.45 & 127.32 & PT 10-15-40 & PT10-25-40 \\
\hline 44 & w & & 138.20 & 140.06 & PT $10-15-44$ & PT10-25-44 \\
\hline 48 & W & Cast & 150.95 & 152.79 & PT 10-15-48 & PT10-25-48 \\
\hline 50 & w & Metal & 157.30 & 159.15 & PT 10-15-50 & PT10-25-50 \\
\hline 60 & W & & 189.10 & 190.99 & PT10-15-60 & PT $10-25-60$ \\
\hline
\end{tabular}

Gambar 8. Pemilihan puli

Kecepatan putaran pada belt, $(n 2)$

$$
\begin{aligned}
n 2 & =\frac{v \times 19100}{D p} \\
& =\frac{0,8 \cdot(19100)}{95,49}=163,01 \mathrm{rpm} \approx 165 \mathrm{rpm} .
\end{aligned}
$$

Peripheral force pada belt. $(F u)$

$$
\begin{aligned}
F u & =\frac{19,1 \times 1 \cdot 000 \cdot 000 \times P d}{D p \times n 2} \\
& =\frac{19,1 \cdot(1 \cdot 000 \cdot 000) \cdot(0,66)}{95,49 \cdot(165)}=800,08 \mathrm{~N}
\end{aligned}
$$

Torsi yang dibutuhkan untuk menggerakan belt, $(T q)$

$$
\begin{aligned}
T q & =\frac{F u \times D p}{2000} \\
& =\frac{800,08 \cdot(95,49)}{2000}=38,20 \mathrm{Nm} .
\end{aligned}
$$

Number of teeth meshing in drive pulley, $(\mathrm{Zm})$

$Z_{m}=Z \times \frac{\operatorname{arc~of~contact}}{360^{\circ}}=30 \cdot \frac{180^{\circ}}{360^{\circ}}=15$

Tooth share strength, $\left(F p_{\text {spec }}\right)$

$F p_{\text {spec } @ 165 r p m}=\frac{F p_{\text {spec }}-F p_{\text {spec }_{1}}}{F p_{\text {spec }_{2}}-F p_{\text {spec }_{1}}}=\frac{r p m-r p m_{1}}{r p m_{2}-r p m_{1}}$

$F p_{\text {spec } @ 165 \mathrm{rpm}}=42,4 \mathrm{~N} / \mathrm{cm}$.

Belt width, $(B W)$

$$
\begin{aligned}
B W & =\frac{F u \times K s \times 10}{F p_{\text {spec }} \times Z_{m}} \\
& =\frac{800,08 \cdot(1,7) \cdot(10)}{42,4 \cdot(15)}=21,4 \mathrm{~mm} \approx 100 \mathrm{~mm} .
\end{aligned}
$$

Diambil belt width $100 \mathrm{~mm}$ dengan berat belt $(\mathrm{Bb})=600$ $\mathrm{g} / \mathrm{m}=0,6 \mathrm{~kg} / \mathrm{m}$, sesuai dengan lampiran.

Panjang belt / pitch length, (Lp)

$$
\begin{aligned}
L p & =2 \times C+\frac{\pi(D p+D p)}{2} \\
& =2 .(2.830)+\frac{\pi(95,49+95,49)}{2} \\
& =5.959,99 \mathrm{~mm}=5.96 \mathrm{~m} .
\end{aligned}
$$

Berat belt total, (Wbe)

$W b e=L p \cdot B b \cdot g=5,96 \cdot(0,6) \cdot(9,8)=35,05 N$

Pre-tension force pada belt, $(F p)$

$F p=F u=800,08 \mathrm{~N}$.

\section{G. Pemilihan Motor}

Dalam pemilihan motor ini, akan dipakai motor ac 3 phas dengan melihat katalog TECO. Spesifikasi ini dipilih berdasarkan kebutuhan yang telah dihitung di atas adalah:

a. Tipe motor : TECO 3 phase Induction Motor.

b. Seri : AESV2E.

c. Daya output,Pm: $1,1 \mathrm{~kW}=1,5 \mathrm{HP}$.

d. Putaran, n1 : $690 \mathrm{rpm}$.

e. Torsi $\max . \quad$ : $15,20 \mathrm{Nm}$.

f. Berat motor : $44,5 \mathrm{~kg}$.

g. Efficiency : $74,7 \%$.

h. Power factor : 67,5.

i. Current : $3,15 \mathrm{~A}$.

j. Diameter Shaft $: 24 \mathrm{~mm}$.

k. Panjang shaft extension: $50 \mathrm{~mm}$. [11]

\section{H. Perancangan Transmisi}

Daya yang akan ditransmisikan dan jarak sumbu poros, Faktor koreksi diambil 1,6 sesuai dengan Tabel koreksi.

$$
\begin{aligned}
\mathrm{Pd} & =\mathrm{fc} . \mathrm{Pm} \\
& =1,6 \cdot(1,1)=1,76 \mathrm{~kW}
\end{aligned}
$$

Perbandingan putaran (i)

$\mathrm{n} 1=690 \mathrm{rpm}$.

$\mathrm{n} 2=165 \mathrm{rpm}$.

$i=\frac{n 1}{n 2}=\frac{690}{165}=4,2$

Torsi yang direncanakan, (Td1) dan (Td2)

$$
\begin{aligned}
T d 1 & =9,74 \times 10^{5} \times \frac{P d}{n 1} \\
& =9,7410^{5} \cdot\left(\frac{1,76}{690}\right) \\
& =2.484,4 \mathrm{~kg} \cdot \mathrm{mm}=24,36 \mathrm{Nm}=24.360 \mathrm{Nmm} . \\
T d 2 & =9,74 \times 10^{5} \times \frac{P d}{n 2} \\
& =9,74 \times 10^{5} \times\left(\frac{1,76}{165}\right) \\
& =10.389,3 \mathrm{~kg} \cdot \mathrm{mm}=101,88 \mathrm{Nm}=101.880 \mathrm{Nmm} .
\end{aligned}
$$

I. Pemilihan Penampang Sabuk [12]

Pada pemilihan penampang sabuk dipilih dengan melihat Gambar 9, sesuai dengan perbandingan antara kecepatan puli kecil yang telah dihitung serta daya yang direncanakan. 


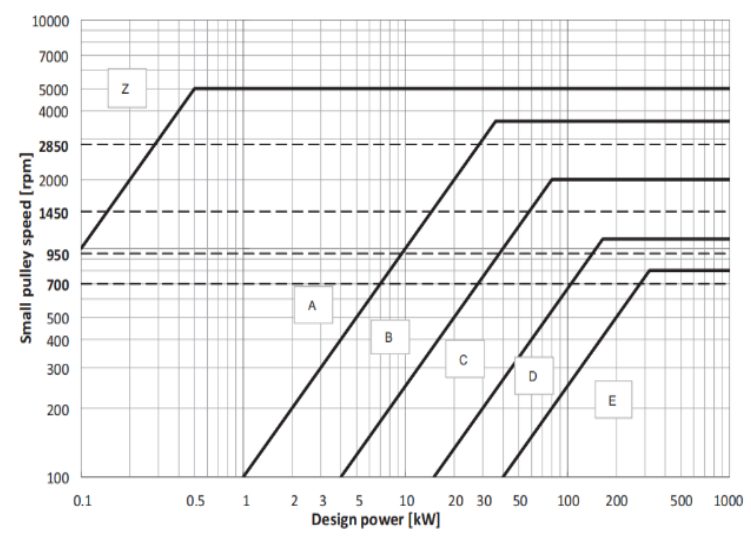

Gambar 9. Grafik pemilihan penampang sabuk

Dari Gambar 9 grafik pemilihan penampang sabuk, akan dipilih yang sesuai dengan putaran puli kecil 165 rpm dan daya rencana $1,76 \mathrm{~kW}$ yaitu, penampang A.

\section{J. Pemilihan diameter puli minimum}

Pada pemilihan diameter puli minimum, ditunjukkan pada Gambar 10. ddmin merupakan datum diameter puli kecil sedangkan DDmin merupakan datum diameter puli besar.

\begin{tabular}{|l|c|c|c|c|c|c|}
\hline \multicolumn{1}{|c|}{ Belt type } & Z & A & B & C & D & E \\
\hline For wrapped type & 45 & 71 & 112 & 180 & 315 & 450 \\
\hline For raw edge cogged type & 40 & 63 & 90 & 140 & - & - \\
\hline
\end{tabular}

Gambar 10. Datum diameter puli minimum

Sesuai Gambar 10, datum diameter puli minimum adalah $71 \mathrm{~mm}$ untuk Wrapped type dengan penampang sabuk A.

$\mathrm{ddmin}=71 \mathrm{~mm}$.

\section{K. Dimensi Puli}

Dari Gambar 11 datum diameter puli minimum, dapat ditentukan datum diameter puli kecil dan puli besar.

$$
\begin{aligned}
\text { ddp } & =90 \mathrm{~mm} . \\
\text { DDp } & =\text { ddp. } \mathrm{i} \\
& =90 .(4,2)=378 \mathrm{~mm} .
\end{aligned}
$$

\begin{tabular}{|c|c|c|c|c|c|c|}
\hline Belt type & Z & A & B & C & D & E \\
\hline Difference & 5.0 & 6.6 & 8.4 & 11.4 & 16.2 & 24.0 \\
\hline
\end{tabular}

Gambar 11. Perbedaan diameter puli minimum

Gambar 11 menunjukan perbedaan antara outside diameter dan datum diameter, yang dimana tipe $\mathrm{A}$ menunjukkan 6,6. Do merupakan outside diameter puli besar sedangkan do merupakan outside diameter puli kecil.

$\mathrm{do}=\mathrm{ddp}+(6,6)$

do $=90+(6,6)=96,6 \mathrm{~mm}$.

$\mathrm{D} 0=\mathrm{DDp}+(6,6)$
$\mathrm{D} 0=378+(6,6)=384,6 \mathrm{~mm}$.

L. Panjang Sabuk, $(L d)$

Panjang sabuk, $L d$ jenis dan tipe belt mitsuboshi yang dirancang:

$$
\begin{aligned}
& L d=2 C+1,57(D D p+d d p) \\
& \quad=2 .(300)+1,57(90+378) \\
& \quad=3034,76 \mathrm{~mm} \approx 3048 \mathrm{~mm} .
\end{aligned}
$$

Sesuai dengan lampiran, dipilih tipe belt A 20 dari Mitsuboshi V-Belt.

\section{Beban v-belt, $(B v)$}

W merupakan beban belt per meter sesuai dengan lampiran.

$$
\begin{aligned}
& B v=W \cdot L d \cdot g \\
& \quad=0,12 \cdot(3,048) \cdot(9,8)=3,59 \mathrm{~N} .
\end{aligned}
$$

N. Kecepatan Sabuk, v

Sesuai referensi peancangan $v$-belt katalog mitsuboshi $v$-belt, kecepatan $v$-belt tidak boleh melebihi $30 \mathrm{~m} / \mathrm{s}$.

$$
\begin{aligned}
v & =\frac{\pi \cdot d o \cdot n 1}{60 \cdot 1000} \\
& =\frac{\pi \cdot(96,6) \cdot(690)}{60 \cdot(1000)}=3,49 \mathrm{~m} / \mathrm{s} .
\end{aligned}
$$

\begin{tabular}{|c|c|c|c|c|c|c|c|c|}
\hline \multirow{2}{*}{$\begin{array}{l}\text { Length } \\
\text { designation }\end{array}$} & \multirow{2}{*}{ Datum length $(\mathrm{mm})$} & \multicolumn{6}{|c|}{ Installation allowance $(\mathrm{mm})$} & \multirow{2}{*}{$\begin{array}{l}\text { Take-up allowance (mm) } \\
\text { All sections }\end{array}$} \\
\hline & & $z$ & A & $B$ & $\mathrm{c}$ & $D$ & $\mathrm{E}$ & \\
\hline $20 \sim 38$ & $500 \leqq L d<970$ & 15 & 20 & 25 & & & & 25 \\
\hline $39 \sim 60$ & $970 \leqq L d<1500$ & 20 & 20 & 25 & 40 & & & 40 \\
\hline $61 \sim 90$ & $1500 \leqq L d<2200$ & & 20 & 35 & 40 & & & 50 \\
\hline $91 \sim 120$ & $2200 \leqq L d<3000$ & & 25 & 35 & 40 & & & 65 \\
\hline $121 \sim 158$ & $3000 \leqq L d<4000$ & & 25 & 35 & 40 & 50 & & 75 \\
\hline $159 \sim 195$ & $4000 \leqq L d<5000$ & & & 35 & 50 & 50 & 65 & 90 \\
\hline $196 \sim 240$ & $5000 \leqq L d<6000$ & & & 40 & 50 & 50 & 65 & 100 \\
\hline $241 \sim 270$ & $6000 \leqq L d<6800$ & & & & 50 & 65 & 65 & 115 \\
\hline $271 \sim 330$ & $6800 \leqq L d<8400$ & & & & 50 & 65 & 75 & 130 \\
\hline $331 \sim 400$ & $8400 \leqq L d<10000$ & & & & 50 & 65 & 75 & 155 \\
\hline $400 \sim$ & $10000 \leqq L d$ & & & & & 75 & 90 & $L d \times 0.015$ \\
\hline
\end{tabular}

Arc of contact puli kecil, $(\theta 1)$

$$
\begin{aligned}
\theta 1 & =180-2 \sin ^{-1} \frac{D D p-d d p}{2 C} \\
& =180-2 \sin ^{-1} \frac{378^{-9}-90}{2 \cdot(300)}=122,63^{\circ} \approx 123^{\circ}
\end{aligned}
$$

Arc of contact puli besar, $(\theta 2)$

$$
\begin{aligned}
\theta 2 & =180+2 \sin ^{-1} \frac{D D p-d d p}{2 C} \\
& =180+2 \sin ^{-1} \frac{378-90}{2 \cdot(300)}=237,37^{\circ} \approx 238^{\circ}
\end{aligned}
$$

\section{O. Installation and Take-up Allowance,}

Pada tahap ini, dapat dipilih instalasi pemasangan $v$ belt dan take-up yang diperbolehkan sesuai dengan Gambar 12 .

Gambar 12. Perbedaan installation and take-up allowance

Sesuai dari Gambar 12, terlihat bahwa installation allowance yaitu $25 \mathrm{~mm}$ dan take-up allowance yaitu 75 mm. [12] 


\section{P. Analisis Poros}

Pada poros ini, terdapat beberapa gaya yang ditimbulkan v-belt dan puli serta gaya dari konveyor. Terdapat gaya radial pada puli dan belt konveyor serta pembebanan pada puli dan v-belt transmisi. Berikut merupakan gaya-gaya tersebut.

$$
\begin{aligned}
\text { Prk } & =\frac{2 \cdot T q}{D p} \\
& =\frac{2 \cdot(38,20)}{95,49}=804,21 \mathrm{~N} . \\
\text { Fs } & =2 \cdot \mathrm{nb} \cdot \text { To } \cdot \sin \frac{\theta 2}{2} \cdot 1,5 \\
& =2 \cdot 1 \cdot 314,96 \cdot \sin \frac{238}{2} \cdot 1,5=826,41 \mathrm{~N}
\end{aligned}
$$

Prk merupakan gaya radial pada konveyor sedangkan Fs merupakan gaya radial pada transmisi v-belt. Dari 2 gaya tersebut, terdapat penambahan gaya pada bantalan di poros, yang diberi simbol Ra dan Rb. Gambar 13 menunjukkan diagram benda bebas (DBB) poros output. [13]

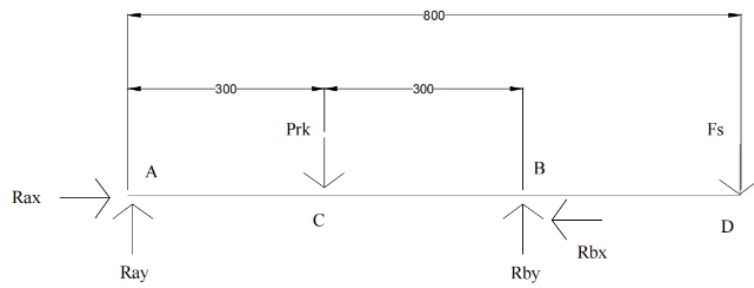

Gambar 13. DBB poros output

$\sum M_{a}=0$

$R_{b y}(600)-P_{r k}(300)-F_{S}(800)=0$

$R_{b y}(600)-804,21 .(300)-826,41 .(800)=0$

$R_{b y}=\frac{836278,2}{600}=1503,99 \mathrm{~N}$.

$\sum F_{y}=0$

$R_{B y}+R_{A y}-P_{r k}-F_{S}=0$

$R_{a y}=P_{r k}+F_{S}-R_{b y}$

$R_{a y}=804,21+826,41-1503,99=126,63 \mathrm{~N}$,

Gambar 14 menunjukkan gaya dalam untuk ruas AC

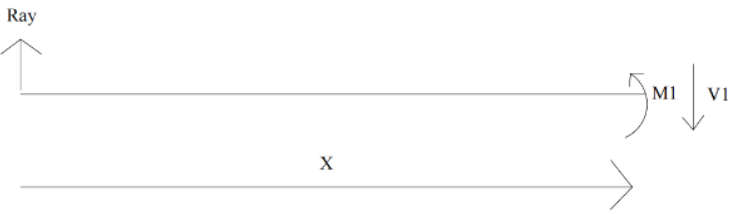

Gambar 14. Gaya dalam untuk ruas AC

$\sum F_{y}=0$

$R_{a y}-V_{1}=0$

$V_{1}=R_{a y}=126,63 \mathrm{~N}$ $\sum M_{\text {pot }}=0$

$M_{1}+R_{a y}(x)=0$

$M_{1}=-R_{a y}(x)$

$M_{1}=-126,63(x)$

$x=0 \quad \rightarrow \quad M_{1}=0 \mathrm{Nmm}$

$x=300 \rightarrow M_{1}=-37989 \mathrm{Nmm}$.

Gambar 15 menunjukkan gaya dalam untuk ruas CB

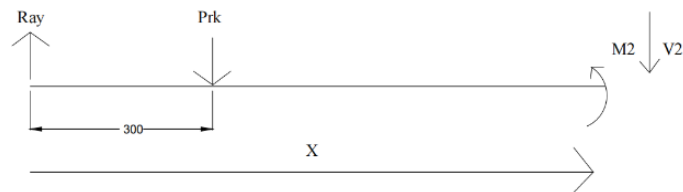

Gambar 15. Gaya dalam untuk ruas CB

$\sum F_{y}=0$

$-V_{2}-P_{r k}+R_{a y}=0$

$V_{2}=R_{a y}-P_{r k}=-677,58 \mathrm{~N}$

$\sum M_{\text {pot }}=0 \mathrm{~m}$

$M_{2}-P_{r k}(x-300)+R_{a y}(x)=0$

$M_{2}=P_{r k}(x-300)-R_{a y}(x)$

$M_{2}=804,21(x-300)-126,63(x)$

$x=300 \rightarrow M_{2}=-37989 \mathrm{Nmm}$.

$x=600 \rightarrow M_{2}=165285 \mathrm{Nmm}$.

Gambar 16 menunjukkan gaya dalam untuk ruas DB

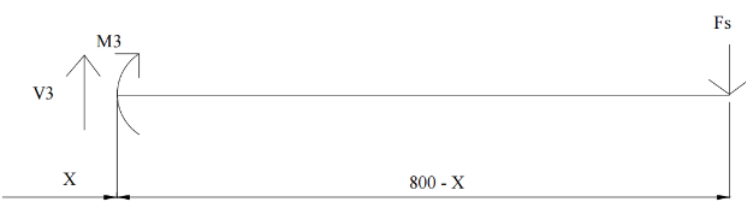

Gambar 16. Gaya dalam untuk ruas DB

$\sum F_{y}=0$

$V_{3}-F s=0$

$V_{3}=F s=826,41 \mathrm{~N}$.

$\sum M_{\text {pot }}=0$

Fs $(800-x)-M_{4}=0$

$M_{3}=F s(800-x)$

$M_{3}=826,41(800-x)$

$x=600 \rightarrow M_{3}=165285 \mathrm{Nmm}$.

$x=800 \rightarrow \quad M_{3}=0 \mathrm{Nmm}$.

Gambar 17 menunjukkan diagram gaya geser poros output. 


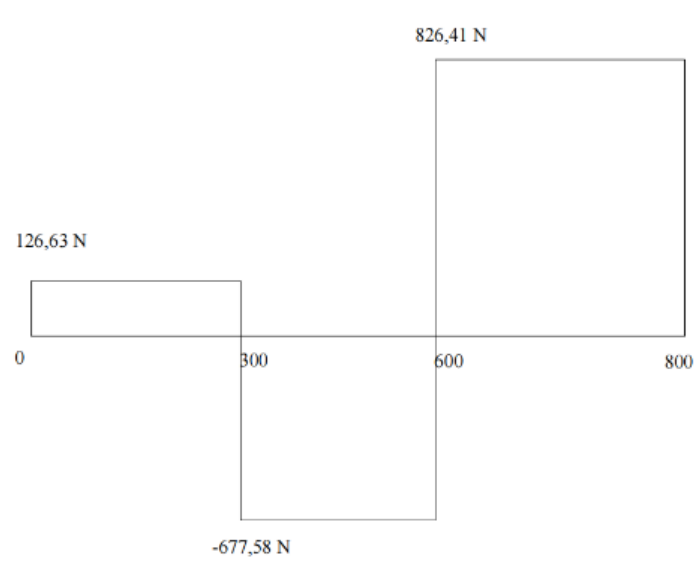

Gambar 17. Diagram gaya geser poros output

Gambar 18 menunjukkan diagram momen lentur poros output.

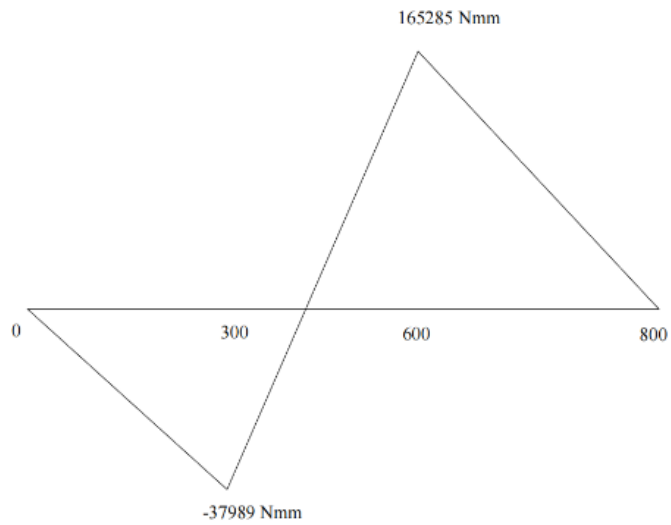

Gambar 18. Diagram momen lentur poros output

\section{Q. Pemilihan Bahan Poros}

Poros umtuk mesin umum biasanya dibuat dari baja batang yang ditarik dingin dan difinis, baja karbon konstruksi mesin (disebut bahan S-C) yang dihasilkan dari killed ingot (baja yang dideoksidasi dengan ferrosilicon dan kemudian dicor sehingga kadar karbon terjamin). Penarikan dingin membuat permukaan poros menjadi keras dan kekuatannya bertambah besar. Bahan poros yang dipilih sesuai dengan Tabel lampiran adalah batang baja yang difinis dingin S45C-D [13].

\section{R. Perhitungan Tegangan Geser Ijin ( $\tau a)$,}

Terkait tegangan geser ijin, diperlukan perhitungan faktor pengaman 1 dan 2 (sf1 \& sf). Untuk itu dipilih sf1 $=6$ dan sf $2=2$. $\sigma_{B}$. Kekuatan tarik bahan poros, yaitu $\sigma_{B}$ $=60 \mathrm{~kg} / \mathrm{mm}^{2}=588,34 \mathrm{MPa}$ sehingga:

$$
\begin{aligned}
\tau \mathrm{a} & =\frac{\sigma_{b}}{s f 1 \times s f 2} \\
& =\frac{60}{6 \cdot(2)}=5 \mathrm{~kg} / \mathrm{mm}^{2}=49,03 \mathrm{~N} / \mathrm{mm}^{2} .
\end{aligned}
$$

S. Perhitungan Diameter Poros, $(d p 1)$ dan $(d p 2)$

Pada perhitungan diameter poros, diperlukan faktor yang dinyatakan dengan $\mathrm{Kt}$ dan faktor pemakaian $\mathrm{Cb}$. Dengan itu, dipilih $\mathrm{Kt}=2$ dan $\mathrm{Cb}=2$.

$$
\begin{aligned}
d p 1 & =\left[\frac{5,1}{\tau a} \text { Kt.Cb.Td1 }\right]^{\frac{1}{3}} \\
& =\left[\frac{5,1}{5} \cdot(2) \cdot(2) \cdot(2 \cdot 484,4)\right]^{\frac{1}{3}} \\
& =21,64 \mathrm{~mm} \approx 24 \mathrm{~mm} .
\end{aligned}
$$

Dari analisis poros, $M_{\text {maks }}=165285 \mathrm{Nmm}$.

Faktor pembebanan lentur yang tetap $(\mathrm{Km})=1,5$

$$
\begin{aligned}
d p_{2} & =\left[\frac{5,1}{\tau_{a}} \times \sqrt{\left(K m \times M_{\text {maks }}\right)^{2}+\left(K t \times T d_{2}\right)^{2}}\right]^{\frac{1}{3}} \\
& =\left[\frac{5,1}{49,03} \times \sqrt{(1,5 \cdot(165.285))^{2}+(2 \cdot(101.880))^{2}}\right]^{\frac{1}{3}} \\
& =32,2 \approx 38 \mathrm{~mm} .
\end{aligned}
$$

T. Pemeriksaan Terhadap Tegangan Tarik maksimum Poros Output

Berdasar Pemeriksaan diameter poros output [14], maka tegangan yang terjadi pada poros output, $\left(\sigma_{\text {poros output }}\right)$

$$
\begin{aligned}
M_{\text {total }} & =\sqrt{{M_{\text {maks }}{ }^{2}+\frac{3}{4} T_{d_{2}}{ }^{2}}^{2}} \\
& =\sqrt{(165.285)^{2}+\frac{3}{4}(101.880)^{2}} \\
& =187.360,03 \mathrm{Nmm} .
\end{aligned}
$$

$d p 2=\sqrt[3]{\frac{10 \times M_{\text {total }}}{\sigma_{\text {poros output }}}}$ atau $38=\sqrt[3]{\frac{10 \cdot(187360,03)}{\sigma_{\text {poros output }}}}$

$38=\left(\frac{10 \times 187360,03}{\sigma_{\text {poros output }}}\right)^{\frac{1}{3}}$ atau $38^{3}=\frac{10 \cdot(187 \cdot 360,03)}{\sigma_{\text {poros output }}}$

$\sigma_{\text {poros output }}=34,15 \frac{\mathrm{N}}{\mathrm{mm}^{2}}=34,15 \mathrm{MPa}$.

$\sigma_{\text {poros output }}<\sigma_{b}$

34,15 $M P a<588,34 M P a \rightarrow$ sudah sesuai dengan batas tegangan tarik yang terjadi pada poros.

\section{U. Pemasangan Bucket pada Konveyor}

Pada pemasangan bucket, digunakan baut heksagonal, mur, lockwasher, dan leather washer. Baut yang dipakai ukurannya bisa disesuaikan dengan kebutuhan. Dalam perancangan ini, digunakan baut M10. Pada Gambar 19, ditunjukkan cara pemasangan pada sabuk [6].

\section{Gambar Teknik Rancangan}

Gambar Teknik diperlukan agar sebagai alat komunikasi antara perencana dan pelakasana untuk kedepannya, agar mudah dalam memproduksi rancangan ini sesuai dengan fungsinya. Gambar 20 adalah gambar teknik perancangan konveyor pengangkut sampah dari dasar sungai. 


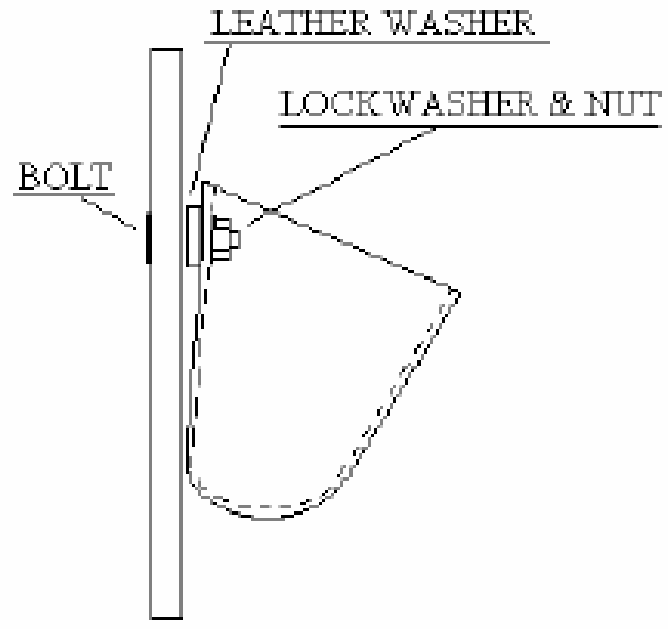

Gambar 19. Cara pemasangan bucket pada sabuk

\section{KESIMPULAN DAN SARAN}

\section{A. Kesimpulan}

Kesimpulan yang diperoleh dari penelitian ini adalah perancangan konveyor pengangkut sampah untuk menanggulangi masalah banjir di perkotaan terutamanya di sungai. Dapat mengetahui bagaimana perancangan serta bagian-bagian dari sabuk konveyor.

Diperoleh varian terbaik adalah varian 3, dengan kombinasi prinsip solusi penggerak motor ac, prinsip solusi transmisi $v$-belt, dan prinsip solusi pengangkut bucket conveyor. Mekanisme penggerak menggunakan motor induksi 3 fasa 1,1 kW dari TECO.

Kapasitas maksimal konveyor adalah 288 ton/hr dengan bekerja selama $10 \mathrm{jam} / \mathrm{hari}$. Pada konveyor menggunakan sabuk dan puli dari Mitsuboshi dengan tipe adalah 100 T10 dan PT-10-30. Transmisi menggunakan $v$-belt dan puli dari Mitsuboshi dengan tipe secara berurutan adalah A 20 dan Single Groove Belt Section A.

Keuntungan yang paling krusial pada rancangan ini dibandingkan dengan metode-metode yang telah disebutkann diatas adalah efektivitas dan efisiensi dalam pengangkatan sampah di sungai. Terutama dalam hal waktu, biaya, dan tenaga yang perbandingannya cukup signifikan.

Ukuran utama pada konveyor mempunyai Panjang $2.830 \mathrm{~mm}$, dengan lebar $800 \mathrm{~mm}$, dan tinggi $2.000 \mathrm{~mm}$. untuk memudahkan pemasangan dipakai bantalan jenis pillow block ball bearing dari SKF [15].

\section{B. Saran}

Setelah dilakukan perancangan konveyor pengangkut sampah dari dasar sungai, terdapat beberapa saran bagi pembaca, yaitu:

a. Sebaiknya perancangan dilakukan dengan fokus ke data lapangan.

b. Sungai yang dimana akan ditempatkan konveyor harus sesuai dengan spesifikasi konveyor.

c. Untuk faktor pengaman, dapat dibuat sekat sebelum sampah menuju konveyor. Hal ini dilakukan agar mengurangi faktor yang dapat merusak konveyor pengangkut sampah dari dasar sungai.

d. Sebaiknya dilakukan analisis lebih lanjut agar konveyor dapat bekerja lebih efektif dan efisien.

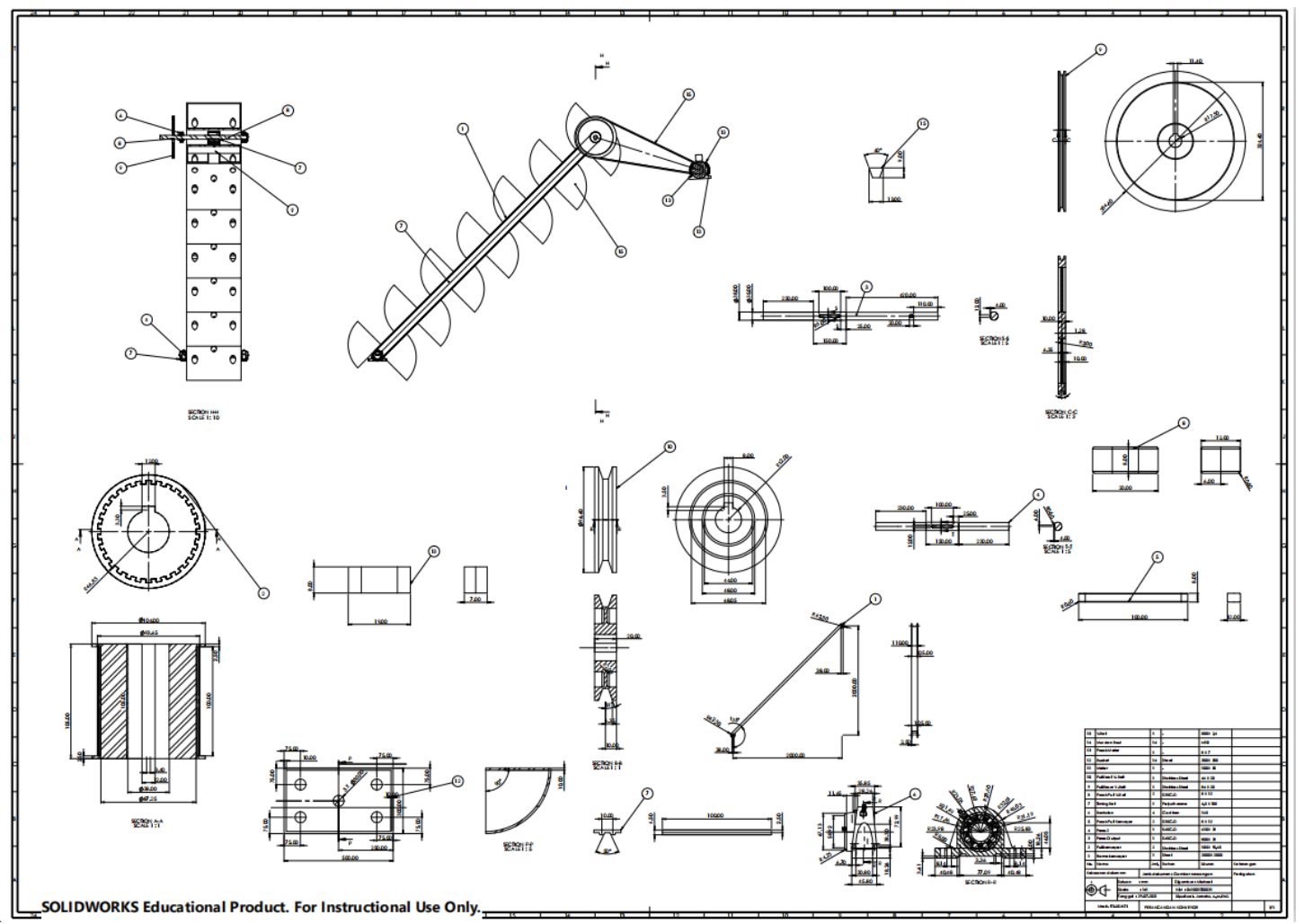

Gambar 20. Gambar teknik rancangan 


\section{Ucapan Terima Kasih}

Ucapan terima kasih kepada Jurusan Teknik Mesin Fakultas Teknologi Industri Universitas Trisakti, dan Lembaga penelitian dari Trisakti yang telah mendukung kegiatan selama ini serta masyarakat sekitar Sungai Sekretaris, Duri Kepa, Jakarta Barat.

\section{DAFTAR PUSTAKA}

[1] R. Adhiharto, Perancangan konstruksi trash bucket conveyor (TBC) sebagai mekanisme pembersih sampah di sungai, Teknik Perancangan Manufaktur, no. 13, 2018, pp. 16.

[2] J. Dobiki, Analisis ketersediaan prasarana persampahan di Pulau Kumo Dan, Jurnal Spasial, vol. 5, no. 221, 2018,pp. 220-228.

[3] [UU] Undang-Undang Republik Indonesia Nomor 18, 2008.

[4] Direktorat Jenderal Pengelolaan Sampah, Limbah dan B3, Kementerian Lingkungan Hidup dan Kehutanan, Sistem Informasi Pengelolaan Sampah Nasional, Website: https://sipsn.menlhk.go.id/sipsn/public/, diakses 12 Juni 2021.

[5] M. Z. Elamin, Analisis pengelolaan sampah pada masyarakat desa Disanah kecamatan sreseh kabupaten sampang, Jurnal Kesehatan Lingkungan, Vol. 10, No. 4, 2018, pp. 5-8.

[6] S. Theodore H. Allegri, Materials Handling Principles and Practice, Delhi: Van Nostrand Reinhold Company Inc., 1987.

[7] A. Hughes, Electric Motor and Drives, Oxford: Elsevier Ltd., 2006.

[8] Noor Edy, M. Jamal, Afiff, Development of waste crusher prototype as disaster mitigation, Jurnal Teknik Mesin Indonesia, vol. 15, 2020, pp. 23-28.

[9] Mitsuboshi, Mitsuboshi Freespan Belt Catalogue, Tokyo, 2020.

[10] Mitsuboshi, Design Manual Timing Belt Catalogue, Tokyo, 2020.

[11] TECO e-Motion, Standard Motor Catalogue, Taipei, 2014.

[12] Mitsuboshi, Design Manual V-Belt DIN Catalogue, Tokyo, 2014.

[13] Sularso; Suga, Kiyokatsu, Dasar Perencanaan dan Pemilihan Elemen Mesin, Jakarta: Pradnya Paramita, 2002.

[14] R. S. Khurmi and J. K. Gupta, A Textbook of Machine Design, New Delhi: Eurasia Publishing House (PVT.) LTD, 2005.

[15] SKF, Rolling Bearing Catalogue, Gothenburg, 2018. 